\title{
OPTIMASI SUDUT UJUNG PIPA PENANGKAPAN GAS METANA PADA METODE ARROW SYSTEM
}

\author{
ZAMZAMI SEPTIROPA, ${ }^{1}$ A. FAUZAN H.S, ${ }^{2}$ MOCH ZAINUDDIN ${ }^{3}$ \\ 1,3 Jurusan Teknik Sipil Fakultas Teknik Universitas Muhammadiyah Malang \\ ${ }^{2}$ Jurusan Teknik Mesin Fakultas Teknik Universitas Muhammadiyah Malang \\ E-mail: zamzami@umm.ac.id
}

\begin{abstract}
ABSTRAK
Sistem pengeboran pada tumpukan sampah untuk mendapatkan gas metan sangat sulit karena sebagian besar sampah adalah terbuat dari plastik sehingga dapat terjebak dalam bor. Penggalian manual tidak diizinkan karena sangat berbahaya, sementara menggali dengan alat berat belum mampu untuk dilakukan karena membutuhkan alat khusus yang mampu mendorong dan menarik permukaan limbah. Membuat lubang dengan metode arrow system yakni mata panah yang lebih besar dari gagang panah, adalah salah satu alternatif yang dapat dicoba untuk mendapatkan lubang/sumur ekstraksi gas di TPA Supit Urang - Malang. Hasilnya, lubang yang lebih besar dari poros panah kemudian diisi dengan kerikil seperti metana ekstraksi baik di TPA. Tumpukan gaya yang dibutuhkan (arrow system) untuk tiang dengan diameter tiang $26,7 \mathrm{~cm}$ dan kedalaman maksimum $5,20 \mathrm{~m}$ (pada titik 1, titik panah dari $30^{\circ}$ dan $45^{\circ}$ ) adalah deretan $63.087 \mathrm{~kg}$ dan 79.717 kg. Sudut optimum dalam hal kebutuhan kekuatan penetrasi tiang dengan sudut mata panah $30^{\circ}$.
\end{abstract}

Kata Kunci: Gas metan, Pile Foundation, Arrow System

\begin{abstract}
Drilling system on a pile of waste to get the methane gas is very difficult because the majority of waste is made from plastic so it can get caught in the drill. Manual excavation is not allowed because it is very dangerous, while digging with heavy equipment has not been able to do because it requires a special tool that is able to push and pull waste surface. Making holes with arrow system method that is larger arrowhead from the arrow shaft, is one alternative that can be tried to get a hole/gas extraction wells at the Landfill Supit Urang - Malang. Results hole larger than the arrow shaft is then filled with gravels as well extration methane in the landfill. The force required pile (arrow system) to the pole with pole diameter $26.7 \mathrm{~cm}$ and a maximum depth of $5.20 \mathrm{~m}$ (at point 1, the arrows point of $30^{\circ}$ and $45^{\circ}$ ) is a row of $63,087 \mathrm{~kg} \mathrm{and} 79,717 \mathrm{~kg}$. Optimum angle in terms of penetration force needs is the pole with arrowhead angle $30^{\circ}$.
\end{abstract}

Keywords: Methane gas, Pile Foundation, Arrow System

\section{PENDAHULUAN}

Metana merupakan gas rumah kaca (GRK) yang menyumbang pemanasan global 21 kali lebih besar dari $\mathrm{CO}_{2}$ yang harus dikurangi emisinya dengan cara ditangkap/diekstraksi untuk dijadikan $\mathrm{CO}_{2}$ dengan cara flaring maupun dijadikan bahan bakar pembangkit listrik (Jacobs and Maskan, 2006). Hal yang perlu dilakukan untuk mendapatkan gas metana dalam landfill adalah membuat lubang atau sumuran pada tumpukan sampah yang telah terlapisi oleh tanah atau bahan plastik. Dalam kegiatan ini sistem pengeboran sangat sulit dilakukan karena sampah yang ada mayoritas berbahan plastik sehingga dapat tersangkut pada mata bor.

Penggalian juga kurang baik diterapkan. Karena keterbatasan alat maka lubang yang dihasilkan tidak dapat berbentuk vertikal. Penggunaan eskavator sebagai penggali juga kurang efektif. Lubang yang dihasilkan cenderung memanjang dan kedalamannya tidak maksimum sampai dasar tumpukan sampah (Fauzan, 2008). Pembuatan lubang dengan metode arrow system yaitu mata panah yang lebih besar dari batang panah merupakan salah satu alternatif yang patut dicoba (Baules, 1993).

Hasil lubang yang lebih besar dari batang panah ini sesuai akan kebutuhan lubang dengan dimensi lebih besar dari pipa yang akan dimasukkan untuk kemudian diisi dengan kerikil. Disamping digunakan untuk penangkapan gas metana, kerikil dapat membantu proses penekanan atau penetrasi sistem counter weight atau perlawanan beban. Adaptasi anak panah ini diambil dari teknologi tiang pancang dimana perlawanan ujung dan hambatan lekat menjadi fokus perhitungan. Tujuan dilakukannya penelitian ini untuk mengetahui gaya yang dibutuhkan penetrasi tiang dengan metode 
anak panah pada timbunan sampah di TPA Supit Urang dan sudut yang baik digunakan sebagai mata tiang.

\section{METODE}

\section{Lokasi Tempat dan Waktu Perencanaan}

Perencanaan dilakukan pada lokasi penelitian Universitas Muhammdiyah Malang, tempat pembuangan akhir sampah kota Malang, di Supit Urang. Sel yang dijadikan obyek adalah sel 4 (empat)

\section{Data Perencanaan}

Data yang diperlukan dalam perencanaan ini antara lain data sondir, dimensi arrow system, kedalaman dan luas sel. Data diperoleh berdasarkan data dilapangan dan perencanaan.

Spesifikasi tiang dan mata tiang yang direncanakankan adalah sebagai berikut: Diameter pipa: $26,7 \mathrm{~cm}$; Tebal pipa: 9,5 mm; Luas pipa: $76,97 \mathrm{~cm}^{2}$; Tegangan ijin baja: $1600 \mathrm{~kg} / \mathrm{cm}^{2}$; Berat baja: 1,10 $\mathrm{kg} / \mathrm{cm}$; Modulus elastisitas baja: $2 \times 10^{5} \mathrm{~kg} / \mathrm{cm}^{2}$; Diameter kepala: $60 \mathrm{~cm}$ (dengan alternatif sudut yang mata panah $30^{\circ}, 45^{\circ}, 60^{\circ}$ ).

- Tinggi arrow system

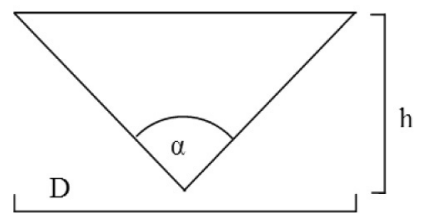

$$
\begin{aligned}
& \mathrm{h} 1=111,96 \mathrm{~cm} \\
& \mathrm{~h} 2=72.43 \mathrm{~cm} \\
& \mathrm{~h} 3=51,96 \mathrm{~cm}
\end{aligned}
$$

- Luas permukaan mata panah

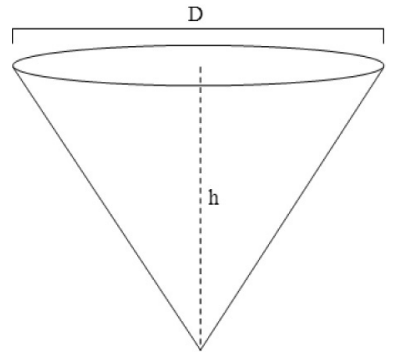

$\mathrm{Ap} 1=7031 \mathrm{~cm}^{2}$

Ap2 $=4548 \mathrm{~cm}^{2}$

Ap3 $=3263 \mathrm{~cm}^{2}$

\section{HASIL DAN PEMBAHASAN}

\section{Pembuatan Sumur Gas}

Pada instalasi penangkapan gas landfill yang mulai dikembangkan adalah dengan sistem pengeboran langsung di tempat pembuangan akhir, pengeboran ini didasarkan pada kedalaman dari tumpukan sampah. Hal ini dilakukan karena umumnya di TPA di Indonesia tidak didesain untuk sanitary landfill sehingga perlu pengeboran, disisi lain kebanyakan juga disusun dengan model open dumping, salah satu bentuk pengeboran sumur gas seperti ditunjukkan pada Gambar 1.

TPA atau landfill yang dipersiapkan dengan baik terdapat sekat pada dasarnya/membrane dasar (base liner) yang terbuat dari geotekstil sehingga akan menahan air dan gas dari keluar atau masuk, pada tiap $50 \mathrm{~cm}$ tebal sampah, dilapisi gragal (batuan kasar) setebal $20 \mathrm{~cm}$. Lapisan batuan ini menjadi jalan gas untuk ke pipa ekstraksi. Jika TPA penuh dan tidak lagi menerima sampah, maka ditutup

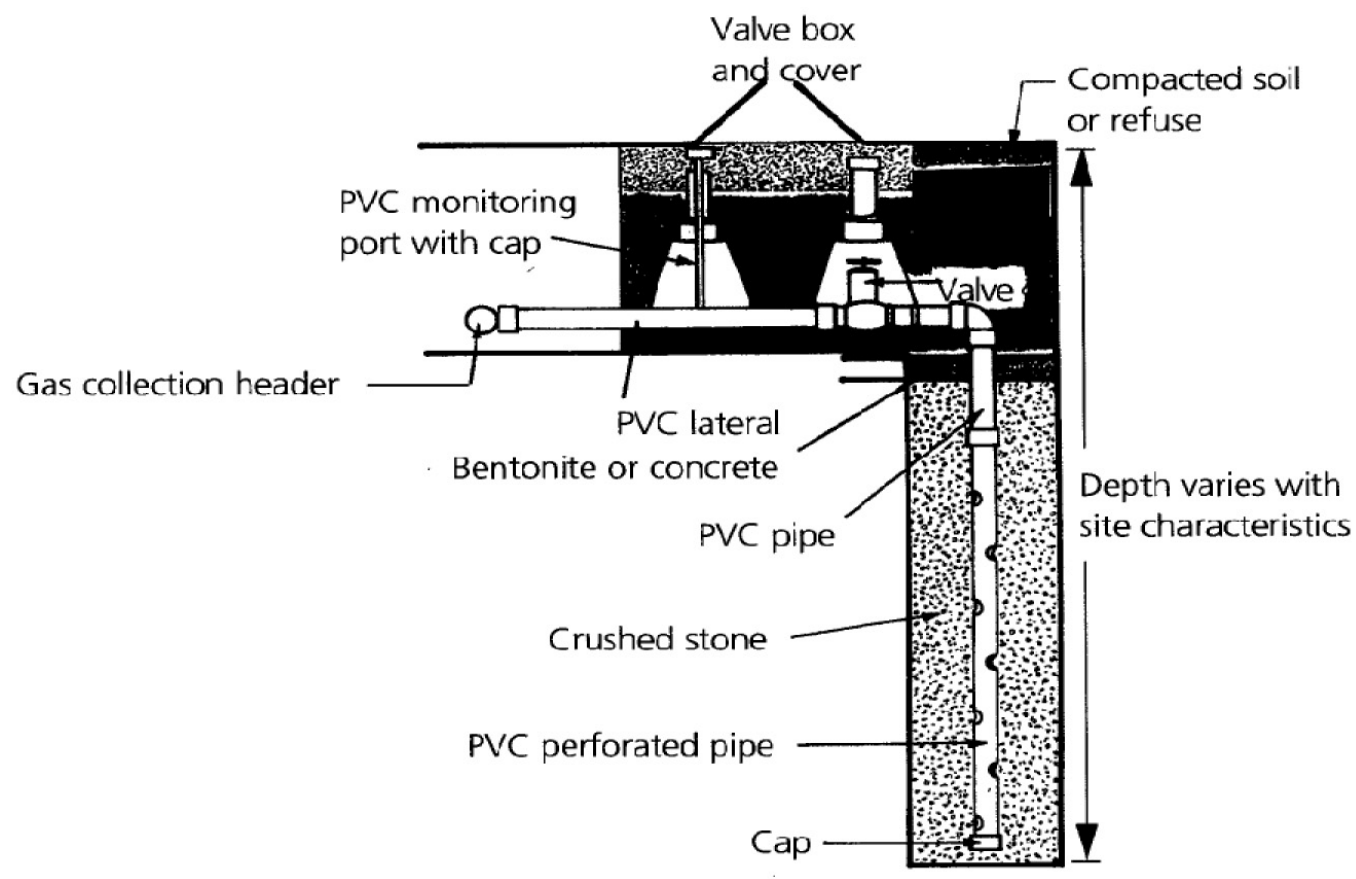

Gambar 1. Lubang Gas Vertikal. 
dengan tanah, dilapisi geotekstil, ditutup tanah lagi yang kemudian ditanami pada bagian atasnya. Sistem ini mengurangi kebocoran gas.

Mengingat sel sel di landfill Malang tidak dipersiapkan dengan baik, sehingga tidak memiliki membrane dasar, tidak ada cukup rongga rongga untuk kelancaran aliran, hal ini menyebabkan gas metan tak dapat diekstraksi dengan baik dan banyak kebocoran.

\section{Konsep Produk Pipa Ekstraksi Vertikal}

Dengan menerapkan teknologi tiang pancang untuk metode system anak panah (arrow system), pipa panangkap gas metan (CH4) dapat dimasukkan ke dalam tumpukan sampah dengan memberikan tekanan sesuai perlawanan yang diberikan melalui hambatan lekat oleh tumpukan sampah. Fungsi dari sistem anak panah adalah memberikan ruang untuk kerikil yang dibutuhkan sebagai daerah aliran gas metan.

Batang dan kepala terbuat dari besi, yang mampu menekan/menusuk tumpukan sampah dengan penekan menggunakan hammer. Di sekelilingnya ditimbuni batuan yang tersedia karena perbedaan dimensi mata dan batang. Jika ditekan ke bawah maka akan masuk ke timbunan sampah dan kerikil dapat masuk ke dalam lubang ekstraksi. Pipa kemudian disambung dan sekelilingnya ditimbun kerikil lagi kemudian ditekan kembali. Demikian dilakukan hingga mencapai dasar tanah. Perkiraan diameter pipa lebih kurang $260 \mathrm{~mm}$ dan perkiraan diameter kepala $600 \mathrm{~mm}$. Ukuran ini hanya perkiraan awal yang akan direvisi berdasar perhitungan.

Pada penelitian ini dihitung spesifikasi pipa yang sesuai agar mampu menahan tekanan/pukulan untuk menusuk masuk ke dalam timbunan sampah.

\section{Daya Dukung Pondasi Tiang Pancang}

Pondasi 1 tiang pancang pada umumnya didukung oleh tanah dengan kondisi:

a. Tiang pancang tertahan ujungnya

Rumus-rumus yang digunakan untuk menahan daya dukung pondasi untuk tiang pancang yang tertahan ujungnya (end bearing pile) adalah:

1. Berdasarkan kekuatan bahan tiang $\mathrm{P}$ tiang $=$ À tiang $\times \mathrm{A}$ tiang.... Persamaan 1

2. Berdasarkan kekuatan tanah

$$
\text { Gtiang }=\frac{\text { A tiang } \times \mathrm{Qc}}{3} \text {. }
$$

b. Tiang yang berdaasarkan gesekan selimut tiang dengan tanah (friction pile)

Rumus-rumus yang digunakan untuk menentukan daya dukung pondasi untuk tiang pancang yang berdasarkan gesekan antara selimut tiang

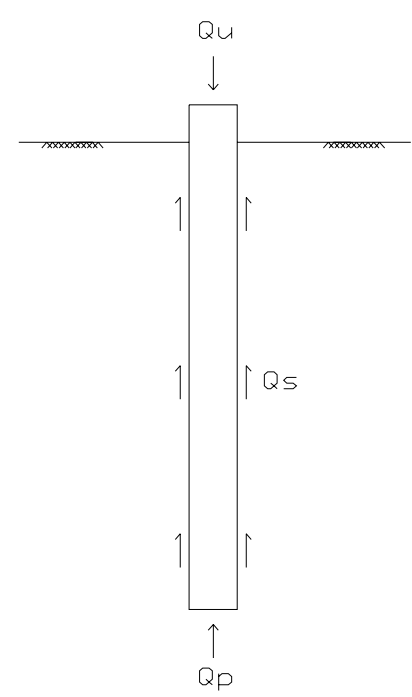

Gambar 2. Daya Dukung Pondasi (End Bearing Pile)

dengan tanah (friction pile) dari hasil data sondir adalah:

Gtiang $=\frac{\text { O.Lc }}{5}$

\section{Kapasitas Penetrasi Arrow System}

Perhitungan kapasitas penetrasi anak panah dilakukan dengan tahap sebagai berikut:

- Kedalaman yang ditinjau $=13,40 \mathrm{~m}$ (didapat dari grafik hasil perhitungan Alat penetrasi tanah Sondir dengan cara mengambil nilai konus terbesar yang terdalam, grafik terlampir)

- Nilai konus $=160 \mathrm{~kg} / \mathrm{cm}^{2}$ (menurut kedalaman yang ditinjau)

- Hambatan lekat rata-rata kedalaman $14 \mathrm{~m}=$ $4,45 \mathrm{~kg} / \mathrm{cm}$ (menurut kedalaman yang ditinjau)

Reaksi pada penetrasi akibat tahanan ujung mata panah dapat dihitung sebagai berikut:

$$
\begin{aligned}
\mathrm{Qp} 1 & =2826.160 \cdot \sin 15^{\circ} \\
& =117562 \mathrm{~kg} \\
\mathrm{Qp} 2 & =2826.160 . \sin 22,5^{\circ} \\
& =171821 \mathrm{~kg} \\
\mathrm{Qp} 3 & =2826.160 . \sin 30^{\circ} \\
& =226080 \mathrm{~kg}
\end{aligned}
$$

Untuk kapasitas penetrasi selimut hanya terjadi pada mata tiang, karena tiang tidak bergesekan dengan timbunan sampah yang disebabkan oleh perbedaan dimensi antara ujung dengan lengan tiang arrow system. Hambatan lekat yang terjadi pada mata anak panah dapat dihitung sebagai berikut:

$$
\begin{aligned}
\mathrm{Qs} 1 & =\mathrm{Ap} 1 \mathrm{Cu} \\
& =7031(4,45)=31288 \mathrm{~kg} \\
\mathrm{Qs} 2 & =\mathrm{Ap} 2 . \mathrm{Cu} \\
& =4548(4,45)=20239 \mathrm{~kg}
\end{aligned}
$$




$$
\begin{aligned}
\text { Qs3 } & =\text { Ap3. Cu } \\
& =3263(4,45)=14520 \mathrm{~kg}
\end{aligned}
$$

Setelah didapat kapasitas penetrasi akibat tahanan ujung dan hambatan lekat, maka dihitung kapasitas bahan Arrow system sebagai berikut.

$$
\begin{aligned}
\mathrm{P} 1 & =\mathrm{Qp} 1+\mathrm{Qp} 1 \\
& =117562+31288=148850 \mathrm{~kg} \\
\mathrm{P} 2 & =\mathrm{Qp} 2+\mathrm{Qp} 2 \\
& =171821+20239=192059 \mathrm{~kg} \\
\mathrm{P} 3 & =\mathrm{Qp} 3+\mathrm{Qp} 3 \\
& =226080+14520=240600 \mathrm{~kg}
\end{aligned}
$$

Kontrol kelangsingan batang dan tegangan

Syarat tegangan $\quad: \sigma=\omega \cdot \frac{P}{A} \leq \bar{\sigma}_{s}=1600 \mathrm{~kg} / \mathrm{cm}^{2}$

Syarat kelangsingan: $\lambda=\frac{L_{k}}{i_{\min }} \leq 200$

$\lambda \mathrm{x}=\frac{L_{k}}{i_{x}}=\frac{1340}{9,12}=147<200 \quad \rightarrow \quad \omega=4,17$

$\sigma 1=\omega \cdot \frac{P}{A}=4,17 \cdot \frac{148850}{76,97}=6847 \mathrm{~kg} / \mathrm{cm}^{2}>\bar{\sigma}$

$\sigma 2=\omega \cdot \frac{P}{A}=4,17 \cdot \frac{192059}{76,97}=9294 \mathrm{~kg} / \mathrm{cm}^{2}>\bar{\sigma}$

$\sigma 3=\omega \cdot \frac{P}{A}=4,17 \cdot \frac{240600}{76,97}=11889 \mathrm{~kg} / \mathrm{cm}^{2}>\bar{\sigma}$
Perhitungan serupa dilakukan dengan cara coba-coba pada kedalaman yang berbeda hingga mendapatkan $\sigma$ Arrow system $<\bar{\sigma}_{\text {ijin }}$. Hasil perhitungan ditabelkan.

\section{Gaya Penetrasi Anak Panah}

Gaya untuk penetrasi anak panah pada timbunan sampah di hitung dari hambatan ujung dan hambatan lekat. Perhitungan mengacu pada hasil penyelidikan sondir yang dilakukan pada 4 titik. Hasil perhitungan gaya yang dibutuhkan untuk memasukkan tiang pancang dengan 3 mata panah sudut $30^{\circ}, 45^{\circ}$, dan $60^{\circ}$ kedalam lapisan timbunan sampah di TPA Supit Urang pada keempat titik ditabelkan sebagai berikut.

Berdasarkan kekuatan tegangan pada setiap anak panah sebesar $1600 \mathrm{~kg} / \mathrm{cm}^{2}$, dapat dilihat pada tabel 1 bahwa mata panah dengan sudut $30^{\circ}$ dan $45^{\circ}$ mampu mencapai kedalaman 5,20 $\mathrm{m}$ dengan gaya berturut-turut sebesar $67287 \mathrm{~kg}$ dan $79717 \mathrm{~kg}$ yang menghasilkan tegangan berturut-turut sebesar $1070 \mathrm{~kg} / \mathrm{cm}^{2}$ dan $1353 \mathrm{~kg} / \mathrm{cm}^{2}$. Pada tabel 2 menunjukkan bahwa kedalaman maksimal yang

\begin{tabular}{|c|c|c|c|c|c|c|c|c|}
\hline $\operatorname{Kedalaman}(\mathrm{cm})$ & 1340 & & 1280 & & 1020 & & 820 & \\
\hline Nilai konus $\left(\mathrm{kg} / \mathrm{cm}^{\wedge} 2\right.$ & 160 & & 150 & & 100 & & 80 & \\
\hline Cleef rata-rata(kg/cm') & 4.45 & & 4.42 & & 4.3 & & 3.6 & \\
\hline Tipe tiang & $\mathrm{Qu}(\mathrm{kg})$ & $\grave{\mathrm{A}}(\mathrm{kg} / \mathrm{cm} \wedge 2)$ & $\mathrm{Qu}(\mathrm{kg})$ & $\grave{\mathrm{A}}(\mathrm{kg} / \mathrm{cm} \wedge 2)$ & $\mathrm{Qu}(\mathrm{kg})$ & $\grave{\mathrm{A}}(\mathrm{kg} / \mathrm{cm} \wedge 2)$ & $\mathrm{Qu}(\mathrm{kg})$ & $\grave{\mathrm{A}}\left(\mathrm{kg} / \mathrm{cm}^{\wedge} 2\right)$ \\
\hline $30^{\circ}$ & 148850 & 6847 & 141291 & 3611 & 103709 & 1727 & 84092 & 1968 \\
\hline $45^{\circ}$ & 192059 & 9294 & 181184 & 4690 & 126944 & 2247 & 102283 & 2393 \\
\hline $60^{\circ}$ & 240600 & 11889 & 226372 & 5891 & 155331 & 2825 & 124787 & 2920 \\
\hline $\operatorname{Kedalaman}(\mathrm{cm})$ & 760 & & 520 & & 300 & & & \\
\hline Nilai konus(kg/cm^2 & 70 & & 60 & & 50 & & & \\
\hline Cleef rata-rata(kg/cm') & 3.3 & & 2.18 & & 1.15 & & & \\
\hline Tipe tiang & $\mathrm{Qu}(\mathrm{kg})$ & $\grave{\mathrm{A}}\left(\mathrm{kg} / \mathrm{cm}^{\wedge} 2\right)$ & $\mathrm{Qu}(\mathrm{kg})$ & $\grave{\mathrm{A}}(\mathrm{kg} / \mathrm{cm} \wedge 2)$ & $\mathrm{Qu}(\mathrm{kg})$ & $\grave{\mathrm{A}}(\mathrm{kg} / \mathrm{cm} \wedge 2)$ & & \\
\hline $30^{\circ}$ & 74636 & 1616 & 63087 & 1070 & 44824 & 634 & & \\
\hline $45^{\circ}$ & 90180 & 1953 & 79717 & 1353 & 58924 & 833 & & \\
\hline $60^{\circ}$ & 109678 & 2375 & 98958 & 1679 & 74402 & 1052 & & \\
\hline
\end{tabular}
dapat dicapai adalah 4,20 m oleh mata panah dengan sudut $30^{\circ}$ dan $45^{\circ}$. Besarnya gaya berturut-turut

\begin{tabular}{|c|c|c|c|c|c|c|}
\hline Kedalaman $(\mathrm{cm})$ & 440 & & 420 & & 340 & \\
\hline Nilai konus(kg/cm^^2 & 150 & & 80 & & 60 & \\
\hline Cleef rata-rata(kg/cm') & 2.3 & & 2.09 & & 1.54 & \\
\hline Tipe tiang & $\mathrm{Qu}(\mathrm{kg})$ & $\grave{A}\left(\mathrm{~kg} / \mathrm{cm}^{\wedge}{ }^{2}\right)$ & $\mathrm{Qu}(\mathrm{kg})$ & $\grave{A}\left(\mathrm{~kg} / \mathrm{cm}^{\wedge} 2\right)$ & $\mathrm{Qu}(\mathrm{kg})$ & $\grave{\mathrm{A}}\left(\mathrm{kg} / \mathrm{cm}^{\wedge} 2\right)$ \\
\hline $30^{\circ}$ & 126385 & 1995 & 73476 & 1142 & 54913 & 798 \\
\hline $45^{\circ}$ & 171542 & 2708 & 95416 & 1483 & 71437 & 1039 \\
\hline $60^{\circ}$ & 219455 & 3464 & 119860 & 1862 & 89805 & 1306 \\
\hline
\end{tabular}
$73476 \mathrm{~kg}$ dan $95416 \mathrm{~kg}$. Nilai tegangan berturutturut $1142 \mathrm{~kg} / \mathrm{cm}^{2}$ dan $1483 \mathrm{~kg} / \mathrm{cm}^{2}$. Pada tabel 3 kedalaman maksimal yang dapat dicapai adalah $4,60 \mathrm{~m}$ oleh mata panah sudut $30^{\circ}, 45^{\circ}$ dan $60^{\circ}$.

Tabel 1. Gaya Penetrasi Tiang Pada Titik 1

Tabel 2. Gaya Penetrasi Tiang Pada Titik 2 
Tabel 3. Gaya Penetrasi Tiang Pada Titik 3

\begin{tabular}{|c|c|c|c|c|c|c|c|c|}
\hline Kedalaman $(\mathrm{cm})$ & & 1440 & & 520 & & 500 & & 460 \\
\hline Nilai konus $\left(\mathrm{kg} / \mathrm{cm}^{\wedge} 2\right.$ & & 160 & & 140 & & 120 & & 55 \\
\hline Cleef rata-rata $\left(\mathrm{kg} / \mathrm{cm}^{\prime}\right)$ & & 4.26 & & 1.94 & & 1.98 & & 1.8 \\
\hline Tipe tiang & $\mathrm{Qu}(\mathrm{kg})$ & $\grave{\mathrm{A}}\left(\mathrm{kg} / \mathrm{cm}^{\wedge} 2\right)$ & $\mathrm{Qu}(\mathrm{kg})$ & $\grave{\mathrm{A}}\left(\mathrm{kg} / \mathrm{cm}^{\wedge} 2\right)$ & $\mathrm{Qu}(\mathrm{kg})$ & $\grave{\mathrm{A}}\left(\mathrm{kg} / \mathrm{cm}^{\wedge} 2\right)$ & $\mathrm{Qu}(\mathrm{kg})$ & $\grave{\mathrm{A}}\left(\mathrm{kg} / \mathrm{cm}^{\wedge} 2\right)$ \\
\hline $30^{\circ}$ & 147514 & 9234 & 116507 & 1977 & 102093 & 1703 & 53068 & 851 \\
\hline $45^{\circ}$ & 191195 & 11968 & 159166 & 2701 & 137871 & 2300 & 67250 & 1078 \\
\hline $60^{\circ}$ & 239980 & 15022 & 204150 & 3464 & 176021 & 2936 & 83588 & 1340 \\
\hline
\end{tabular}

Tabel 4. Gaya Penetrasi Tiang Pada Titik 4

\begin{tabular}{|c|c|c|c|c|c|c|c|c|}
\hline Kedalaman $(\mathrm{cm})$ & & 1100 & & 1060 & & 980 & & 820 \\
\hline Nilai konus $\left(\mathrm{kg} / \mathrm{cm}^{\wedge} 2\right.$ & & 150 & & 140 & & 110 & & 105 \\
\hline Cleef rata-rata $\left(\mathrm{kg} / \mathrm{cm}^{\prime}\right)$ & & 2.57 & & 2.6 & & 2.67 & & 2.83 \\
\hline Tipe tiang & $\mathrm{Qu}(\mathrm{kg})$ & $\grave{\mathrm{A}}\left(\mathrm{kg} / \mathrm{cm}^{\wedge} 2\right)$ & $\mathrm{Qu}(\mathrm{kg})$ & $\grave{A}\left(\mathrm{~kg} / \mathrm{cm}^{\wedge} 2\right)$ & $\mathrm{Qu}(\mathrm{kg})$ & $\grave{\mathrm{A}}\left(\mathrm{kg} / \mathrm{cm}^{\wedge} 2\right)$ & $\mathrm{Qu}(\mathrm{kg})$ & $\grave{A}\left(\mathrm{~kg} / \mathrm{cm}^{\wedge} 2\right)$ \\
\hline $30^{\circ}$ & 128284 & $\mathrm{~h} 4710$ & 121147 & 4088 & 99596 & 2897 & 97048 & 2271 \\
\hline $45^{\circ}$ & 172770 & 6343 & 162168 & 5472 & 130270 & 3789 & 125628 & 2940 \\
\hline $60^{\circ}$ & 220336 & 8090 & 206304 & 6961 & 164142 & 4775 & 157599 & 3688 \\
\hline $\operatorname{Kedalaman}(\mathrm{cm})$ & & 800 & & 660 & & 500 & & 280 \\
\hline Nilai konus $\left(\mathrm{kg} / \mathrm{cm}^{\wedge} 2\right.$ & & 100 & & 90 & & 70 & & 55 \\
\hline Cleef rata-rata $\left(\mathrm{kg} / \mathrm{cm}^{\prime}\right)$ & & 2.76 & & 2.47 & & 2 & & 1.5 \\
\hline Tipe tiang & $\mathrm{Qu}(\mathrm{kg})$ & $\grave{\mathrm{A}}\left(\mathrm{kg} / \mathrm{cm}^{\wedge} 2\right)$ & $\mathrm{Qu}(\mathrm{kg})$ & $\grave{\mathrm{A}}\left(\mathrm{kg} / \mathrm{cm}^{\wedge} 2\right)$ & $\mathrm{Qu}(\mathrm{kg})$ & $\grave{\mathrm{A}}\left(\mathrm{kg} / \mathrm{cm}^{\wedge} 2\right)$ & $\mathrm{Qu}(\mathrm{kg})$ & $\grave{\mathrm{A}}\left(\mathrm{kg} / \mathrm{cm}^{\wedge} 2\right)$ \\
\hline $30^{\circ}$ & 92882 & 2125 & 83495 & 1618 & 65495 & 1093 & 50958 & 710 \\
\hline $45^{\circ}$ & 119940 & 2744 & 107883 & 2091 & 84268 & 1406 & 65885 & 918 \\
\hline $60^{\circ}$ & 150306 & 3439 & 135230 & 2621 & 105436 & 1759 & 82610 & 1152 \\
\hline
\end{tabular}

Besarnya gaya berturut-turut $53068 \mathrm{~kg}, 67250 \mathrm{~kg}$, $83588 \mathrm{~kg}$. Nilai tegangan berturut-turut $851 \mathrm{~kg} / \mathrm{cm}^{2}$, $1078 \mathrm{~kg} / \mathrm{cm}^{2}, 1340 \mathrm{~kg} / \mathrm{cm}^{2}$. Pada tabel 4 kedalaman maksimal yang dapat dicapai adalah 5,00 m oleh mata panah sudut $30^{\circ}$ dan $45^{\circ}$. Besarnya gaya berturutturut $65495 \mathrm{~kg}$ dan $84268 \mathrm{~kg}$. Nilai tegangan berturut-turut $1093 \mathrm{~kg} / \mathrm{cm}^{2}$ dan $1406 \mathrm{~kg} / \mathrm{cm}^{2}$.

\section{Dimensi Mata Panah Efektif}

Dimensi mata panah paling efektif dapat ditentukan dengan mencari gaya terkecil diantara ketiga sudut mata panah $\left(30^{\circ}, 45^{\circ}, 60^{\circ}\right)$. Besarnya gaya terkecil yang menghasilkan tegangan dibawah $1600 \mathrm{~kg} / \mathrm{cm}^{2}$ oleh tiap mata panah pada titik sondir dapat disajikan pada Tabel 5 .

Tabel 5. Perbandingan gaya titik penetrasi

\begin{tabular}{ccccccc}
\hline Nipe anak & \multicolumn{4}{c}{ Gaya Penetrasi (kg) } & Rata- \\
\cline { 3 - 6 } panah & Titik 1 & Titik 2 & Titik 3 & Titik 4 & $\begin{array}{c}\text { rata } \\
\text { (kg) }\end{array}$ \\
\hline 1 & $30^{\circ}$ & 44824 & 54913 & 53068 & 50958 & 50941 \\
2 & $45^{\circ}$ & 58924 & 71437 & 67250 & 65885 & 65874 \\
3 & $60^{\circ}$ & 74402 & 89805 & 83588 & 82610 & 82601 \\
\hline
\end{tabular}

Menurut tabel di atas dapat diketahui bahwa mata panah dengan gaya penetrasi minimum pada kedalaman yang sama dalam 1 titik dan perbandingan dengan titik yang lain adalah tiang dengan mata panah sudut $30^{\circ}$ dengan rata-rata gaya yang dibutuhkan sebesar $50941 \mathrm{~kg}$.

\section{SIMPULAN}

Kedalaman maksimal yang dapat dijangkau yaitu sedalam $520 \mathrm{~cm}$ (pada titik 1, anak panah sudut $30^{\circ}$ dan $45^{\circ}$ ) dengan gaya yang dibutuhkan berturutturut sebesar $63087 \mathrm{~kg}$ dan $79717 \mathrm{~kg}$. Desain dengan sudut $30^{\circ}$ dianggap sudut paling baik dalam hal kebutuhan gaya penetrasi diantara ketiganya.

\section{DAFTAR PUSTAKA}

Fauzan A., 2008. Prediction of Charasteristics the Supit Urang Landfill Production at Malang Regency East Java Indonesia. International Research and Exhibition, BGP Engineers and UMM. 2008. Malang.

AGO, 1997. Methane Capture and Use - Waste management workbook, Department of the Environment and Water Resources.

Anonim, 2008 Desain of Landfill. Terjemahan oleh Tim SWM Universitas Muhammadiyah Malang. 2008. Malang.

Anonim, 2007. Studi kelayakan proyek gas lahan TPA. Makasar. Bank Dunia.

Bowles, J.E., 1993. Analisis dan Desain Pondasi. Terjemahan oleh pantur silaban, Ph.D. 1997. Jakarta. Erlangga.

Jacobs, J. and Maskan, W., 2006. Landfill Gas. Terjemahan oleh Tim SWM Universitas Muhammadiyah Malang. 2008. Malang.

Usepa, 1993. ATSDR. http://www.atsdr.cdc.gov/landfill/ $h t m l / c h 2 . h t m l, U S A$. Terjemahan oleh Tim SWM Universitas Muhammadiyah Malang. 2008. Malang. 
LAMPIRAN

Grafik Sondir
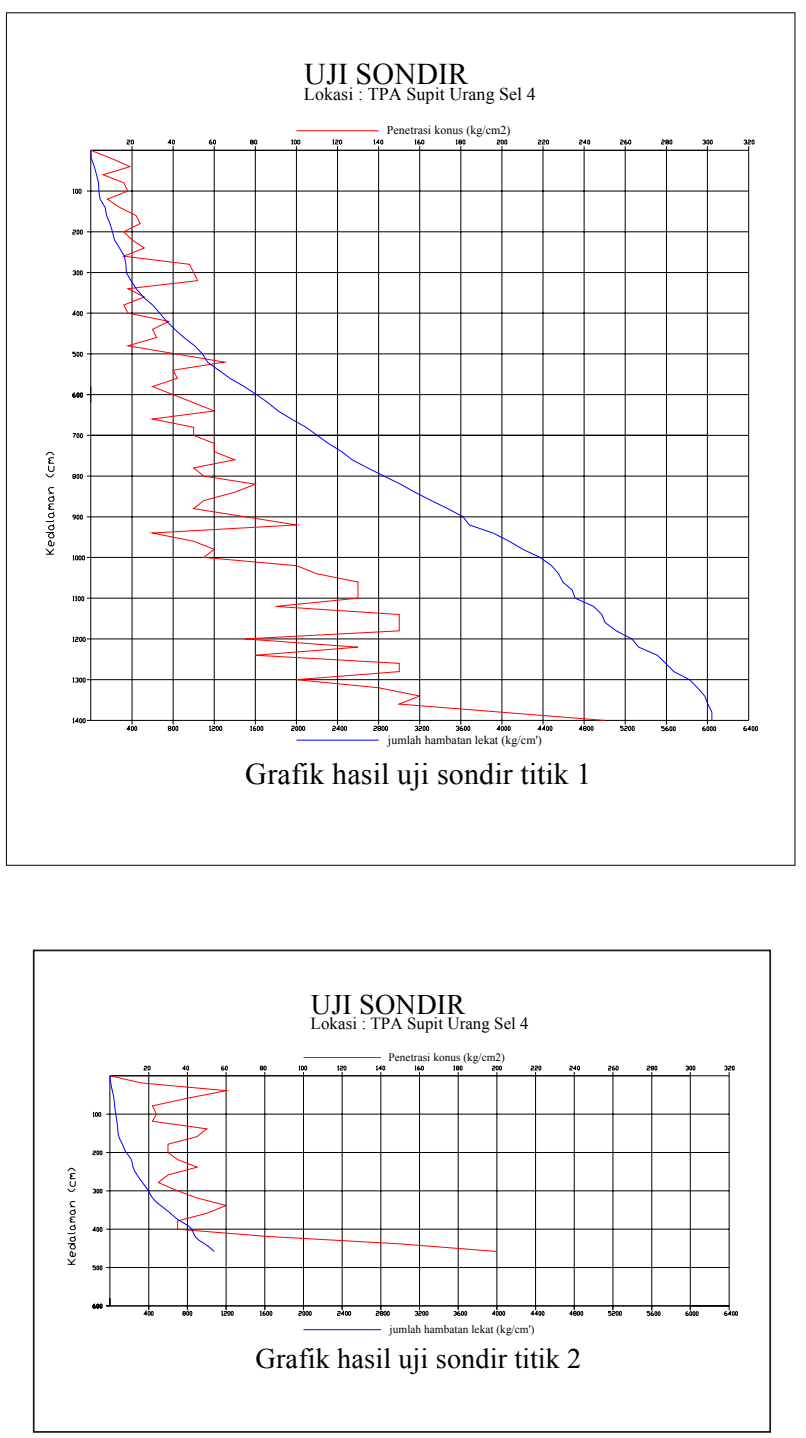

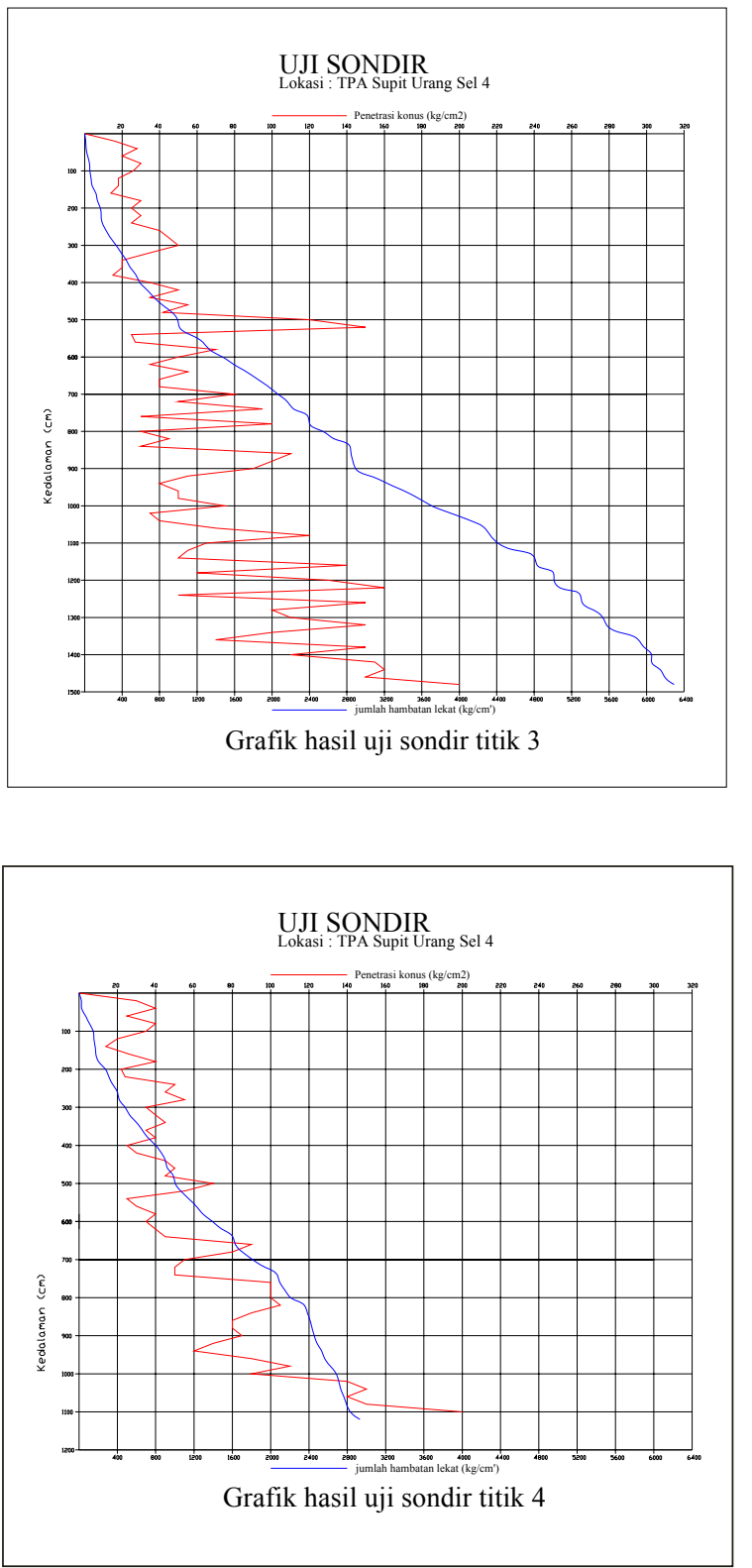

